Modern Asian Studies 52, 3 (2018) pp. 942-970. (C) Cambridge University Press 2018 doi:10.1017/Soo26749X1700004X

\title{
Corruption and Factionalism in \\ Contemporary Punjab: An ethnographic account from rural Malwa
}

\author{
NIGOLAS MARTIN \\ Indology/Modern Indian Studies, Universitat Zurich \\ Email:nicolas.martin@aoi.uzh.ch
}

\begin{abstract}
Over the length of its current tenure, Punjab's Shiromani Akali Dal (SAD) has sought to become more a socially inclusive party, more responsive to popular demands, and even to improve service delivery and eradicate corruption. However, despite these lofty goals, it has also presided over what people refer to as 'goonda raj'- a rule of thugs - and has managed to alienate large sections of the population and, in the process, fuelled the rise of the anti-corruption Aam Admi Party in the state. In this article, based on ethnographic fieldwork in rural Malwa, I attempt to shed light on the roots of this contradiction. Is it simply the case, as ordinary people allege, that the SAD's claims are empty and that its members are merely interested in looting the state? Or, alternatively, is it the case that the party merely operates in accordance with Punjab's allegedly time-honoured tradition of rival factions competing to appropriate the spoils of power? I suggest instead that much of the corruption and violence observable at the village level in Punjab has its roots in the antagonistic relationship between the Congress Party and the Shiromani Akali Dal. It is this antagonism that appears to fuel the SAD's highly partisan form of government, and it is partisan government that appears to fuel the corruption and the village-level factional conflict that is documented in this article.
\end{abstract}

\section{Introduction}

The Shiromani Akali Dal (SAD) Punjabi nationalist party has been in power in Punjab since 2007, and Sukhbir Badal, its president and deputy chief minister until 2017 , repeatedly vowed to rule the state for another 25 years. In order to achieve this end, it has shifted away from its traditional emphasis on Sikh/Punjabi communal issues and towards development. The party has not only reached out to 
Hindu and Scheduled Caste (SC) communities by providing them with government posts, subsidies, and grants, but has also vowed to attract capital to the state and to cleanse it of corruption. In a January 2013 interview with Forbes India, Sukhbir Badal reiterated his grand claim that his party would build airports in every major city in Punjab, and that the most important towns would be connected to each other by four- to six-lane highways. ${ }^{1}$ Badal also vowed to make the police more responsive, to introduce toll-free numbers for distress calls, and to ensure that police officers would reach people within a maximum of ten minutes. With respect to rural development, he vowed to provide all of Punjab's villages with water, drains, and paved roads. Finally, and perhaps most significantly for the purposes of this article, he vowed to rid the state of corruption by introducing e-governance schemes wherever possible.

Akali Dal thinkers believe that corruption is one of the principal obstacles to growth in the state. They often attribute corruption to the Congress Party and its 'licence raj'. Because of bureaucratic inefficiency and corruption, investors and Non-Resident Indians (NRIs) of Punjabi origin do not want to place their money in the state. But the SAD also recognizes that corruption is a key electoral issue, and that to gain and retain power it needs to show a commitment to fighting it. The malaise about corruption is widespread throughout Punjab and dominates everyday conversations. In Patiala district, where I carried out my fieldwork, many young men even cited corruption as one of the main reasons why they want to migrate to the West. They complain about the lack of impartiality in government institutions and the fact that everyone-from police officers to judges to recruitment panels for government jobs-all make their decisions on the basis of political pressure and money. Those who manage to register police FIRs (First Information Reports), they claim, do so through political influence and/or money, and the same is true for those fortunate enough to obtain prized government jobs. Moreover, many complain that the sums involved in these transactions have been increasing. People told me that whereas obtaining a job as Panchayat secretary ${ }^{2}$ cost Rs 20,000 in the 1970s, it now cost around Rs two million.

${ }^{1}$ D. Narayan, 'Sukhbir Singh Badal: 'Punjab Can Become a Natural Investment Destination'. Forbes India, 15 January 2013, http://www.forbesindia. com/article/on-assignment/sukhbir-singh-badal-punjab-can-become-a-naturalinvestment-destination/34511/2, [accessed 5 March 2018].

${ }^{2}$ Panchayat secretaries work at the block level and assist elected village council (Panchayat) representatives in their duties. 
According to Sukhbir Badal and his team, the root cause of corruption lies in the large number of intermediaries between citizens and the state. According to this analysis, brokers or intermediaries are responsible for the fact that only a small proportion of funds and schemes ever reach their intended beneficiaries. The solution, Badal argues, is e-governance. This system permits ordinary citizens to obtain government services without having to resort to intermediaries and to bribing officials. In line with this, the Badal government was swift to computerize land records, making it possible for people to obtain them at the Tehsil headquarters within 15 minutes without having to bribe anyone. Before computerization, people needed to bribe the land record officer (patwari), and it could take several weeks, if not months, to obtain their records. It also opened Suwidha centres where, among other things quickly, people could obtain identity cards, driving licences, and birth certificates. Finally, it also started the process of making Panchayat accounts accessible online, and planned to make it possible to file FIRs online, thereby eliminating the need to bribe police clerks and officers to do so.

What should strike anyone who is acquainted with contemporary Akali politics is the stark contrast between the party's ostensible desire to eradicate corruption and the reality of Akali government on the ground. Throughout my 15 months of fieldwork in Patiala district, countless people alleged that the present tenure of the SAD was the most corrupt of any government to have ever ruled Punjab. During the national elections of 2014 even elderly Sikh nationalists who had supported the party all their lives told me that they would now cast their vote for the anti-corruption Aam Admi Party. They claimed that the old Akali leaders had had morals, but not the current generation: it was only interested in money. Foremost among the accusations against the SAD were claims that senior leaders were behind the state's flourishing trade in opiates. Heroin and poppy-husk addiction were allegedly decimating Punjab's youth, and it was happening because of Akali patronage of drug dealers. Chief among the culprits was the Youth Akali Dal (YAD), the SAD's enforcers, used to harass opponents, rig elections, and distribute drugs to purchase votes during elections. The press frequently reported on the impunity with which YAD members carried out their activities. One article in the Hindustan Times claimed that YAD had killed a young man in Khanna, Ludhiana District, and then drove around flaunting their weapons. It went on to say that 'the way this group escaped brandishing firearms and challenging 
police after the murder shows the criminal mind-set of the Akali leaders'. ${ }^{3}$

The party also stood accused of extorting money and demanding political loyalty from businessmen. It allegedly demanded shares in the profits of all businesses in the state, from roadside restaurants and bus services to commercial property and industry. Businessmen who refuse to pay tribute face bureaucratic hurdles and harassment, with many eventually having to shut down their businesses. I heard stories of police officers preventing cars from parking near restaurants whose owners had refused to pay the SAD, and of businesses having their licences revoked on spurious grounds. In the Patiala district, drivers of light transport vehicles told me of a racket whereby the Ministry of Transport issued SAD cards that allowed drivers to circulate without fear of police harassment. For the privilege, cardholders pay SAD politicians Rs $15^{\circ}$ per month.

Finally, at the village level (where I did my fieldwork), Akali leaders frequently stood accused not only of distributing development funds in a partisan manner, but also of embezzlement and encroaching upon village common lands. ${ }^{4}$ They were alleged to have harassed, and even physically attacked, their opponents. Gill has even argued that the SAD actively distributed weapons to its supporters in order to fight the Congress Party. ${ }^{5}$

Are we to conclude that all of the SAD's policy objectives and pronouncements were merely spin and that everyone, ranging from the village party workers right up to the chief minister, were-as people claimed-only interested in looting the state? Might we perhaps conclude that Akali corruption is characteristic of contemporary India: an India where neoliberal values extolling the virtues of the selfinterested quest for profit now reign supreme? ${ }^{6}$

As I will show, it is certainly true that many local politicians and brokers prospered, thanks to their involvement in politics. Such people

${ }^{3}$ HT Correspondent, 'After Boy's Blood, Anger Spills on Roads'. Hindustan Times, 3 February 2014, http://www.hindustantimes.com/punjab/after-boy-s-bloodanger-spills-on-roads/story-WMmwXKjuDOSrChKahiekeP.html, [accessed 5 March 2018].

${ }^{4}$ N. Martin, 'Rural Elites and the Limits of Scheduled Caste Assertiveness in Rural Malwa, Punjab'. Economic and Political Weekly, Vol L, no. 52, 2015 , pp. 37-44.

${ }^{5}$ S. S. Gill, 'Gun Culture in Punjab'. Economic and Political Weekly, vol. XLVIII, no. 8, 2013 , pp. 16-18.

${ }^{6}$ See R. Dasgupta, Capital: The Eruption of Delhi, Penguin, London, 2014, for a popular account of the rise of the neoliberal, profit-maximizing ethos in India. 
undoubtedly contributed to the 'seepages' that prevent money and development schemes from reaching their intended beneficiaries. But is it the local politicians and brokers, as the SAD leadership claims, who are to blame for widespread seepages and corruption? Is it the case, as Kaviraj argues, that the Indian state has feet of vernacular clay? ${ }^{7}$ Harriss-White refers to the vast assemblage of brokers, advisers, political workers, crooks, and contractors that has arisen around the formal state as a 'shadow state', and argues that it has drained the formal state of funds. ${ }^{8}$ In her account, the losers are the labouring households who make up the bulk of the 'India of the 88 per cent'. 9 Others, such as Jeffrey in the context of Western Uttar Pradesh, ${ }^{10}$ and Pattenden in the context of Karnataka, ${ }^{11}$ likewise emphasize the role of social and political networks in the reproduction of both caste and class hierarchies.

But others also point out that brokers and local politicians can play a constructive role in the delivery of government services and goods. Berenschot, for example, argues that while brokers may indeed block people's access to state resources, they simultaneously play an important role in facilitating access to them. ${ }^{12}$ He argues that the Indian state lacks the resources-in terms of funds, personnel, and capacity - to provide citizens with the expanding number of services that it has been mandated to deliver. This effectively means that citizens find it extremely difficult to access state officials when they need anything, ranging from a pension payment, a land title to a death certificate. This, according to Berenschot, has generated a need for brokers who, for a fee or perhaps a kickback, can help facilitate access to state services through their knowledge of bureaucratic procedures and their contacts with state officials.

${ }^{7}$ S. Kaviraj, 'A Critique of the Passive Revolution'. Economic and Political Weekly, vol. 23, no. 45/47, 1988, pp. 2429-2433, 2436-2441, 2443-2444.

${ }^{8}$ B. Harriss-White, India Working: Essays on Society and Economy, Cambridge University Press, Cambridge, 2003.

${ }^{9}$ Ibid., p. 1.

${ }^{10}$ C. Jeffrey, 'A Fist is Stronger than Five Fingers: Caste and Dominance in Rural North India'. Transactions of the Institute of British Geographers, vol. 26, no. 2, 2001, pp. $217-236$.

${ }^{11}$ J. Pattenden, Labour, State and Society in Rural India: A Class Relational Approach, Manchester University Press, Manchester, 2016.

${ }^{12}$ W. Berenschot, 'Everyday Mediation: The Politics of Public Service Delivery in Gujarat, India'. Development and Change, vol. 41, no. 5, 2010, pp. 883905 . 
Finally, Manor ${ }^{13}$ and Krishna ${ }^{14}$ view certain types of broker in an altogether positive light, arguing that they play a crucial role in bringing the state closer to its citizens. Manor, in particular, describes a specific category of brokers (whom he calls fixers, following Reddy and Haragopal ${ }^{15}$ ) as 'a major national resource, which India possesses in greater abundance than just about any other lessdeveloped country'. ${ }^{16}$ The fixers he describes do not have formal political positions and take a dim view of senior leaders who undermine informal and formal rule-bound governance in the interests of partisan advantage or personal domination. This is because such practices undermine project implementation. While partisan government may allow brokers to accrue personal benefits and to accumulate wealth through corruption, fixers recognize that corruption is also likely to undermine their reputations and future career prospects in politics. This means that fixers avoid formal political and administrative positions. However, in contexts where they are unable to do so because governments expect them to work in a partisan manner, and respond only to mediators who wear party colours, they either have to give up their efforts or cease to be pure fixers-in Manor's as well as in Reddy and Haragopal's sense-to become party-affiliated brokers. ${ }^{17}$ As this article illustrates, such brokers are less able to facilitate the impartial and universal distribution of state resources.

So how are we to reconcile the view that brokers and local politicians are the cause of corruption in India with the opposite view that they can be a major national resource because they play a vital role in helping to bring the state closer to citizens? Manor suggests that it is a particular category of broker-the fixer-who plays a constructive role in mediating between the state and its citizensthat is, it is not just any broker who has a constructive role. His work also suggests that ordinary brokers who might hold government or administrative positions can also play constructive and impartial

${ }^{13}$ J. Manor, 'Small-Time Political Fixers in India's States: "Towel over Armpit"'. Asian Survey, vol. 40, no. 5, 2000, pp. 816-835.

${ }^{14}$ A. Krishna, 'What is Happening to Caste: A View From Some North Indian Villages'. The Journal of Asian Studies, vol. 62, no. 4, 2003, pp. $1171-1193$.

${ }^{15}$ G. Ram Reddy and G. Haragopal, 'The Pyraveekar: "The Fixer" in Rural India'. Asian Survey, vol. 25, no. 11, 1985, pp. 1148-1162.

${ }^{16}$ Manor, 'Small-Time Political Fixers', p. 817.

${ }^{17}$ According to Manor's definition, fixers do not have formal political positions. In this article I use the broader term 'brokers' to include all of those people who mediate between citizens and the state regardless of whether they have formal political positions. 
roles in mediating between citizens and the state-when state-level regimes allow them to do so. In other words, his work also suggests that the extent to which brokers can play a constructive role is related to the sort of political leadership in power at the state level. He argues that politicians can either be inclusive and try and help as many people as possible gain access to the state, or they can be partisan 'control freaks' who only help supporters and who engage in a politics of spite towards opponents. When politicians are inclusive, they are responsive to the requests of both citizens and the brokers that represent them, regardless of their political affiliations. In such situations, both independent fixers and brokers with formal government or administrative positions are allowed to provide their services on a broadly universal basis. When party leaders are partisan, or even spiteful, they serve only those constituents who support them or are liable to do so, and only the brokers who help people on this basis are allowed to thrive.

This suggests that in order to analyse the distribution of government benefits it is important to look not only at brokers, but also at senior party leaders and their relationship to both brokers and ordinary constituents. This, as I show, is because senior politicians often play an important role in enabling both brokers and constituents to acquire certain government goods. The brokers examined in this article are not fixers because most of them have formal government positions at the village council (Panchayat) level and are politically affiliated to either the Congress Party or the SAD. My argument is that in the second decade of the twenty-first century under the $\mathrm{SAD}$, fixers could not thrive, and it was not easy for brokers to play a constructive and impartial role, because the SAD governed in the partisan manner that Manor attributes to 'control freaks'. I argue that the high-handedness and corruption that were attributed to the SAD were not so much a function of the inherently greedy/corrupt nature of Akali senior politicians and brokers, nor the essentially factional nature of Jat Sikh politics (see below), but rather a function of the party leaders' desire to capture and retain power at all costs and at the expense of their major opponent, the Congress Party. This antagonistic form of politics, I suggest, lay behind the SAD's governance failures in two ways. First, partisan government prevented the emergence of fixers and of those brokers who might have sought to deliver government goods on a roughly universal basis and gave space, mainly, to corrupt cronies. Secondly, partisan government either exacerbated or gave rise to conflicts that prevented 
villagers from cooperating in order to implement village development schemes.

\section{Factionalism in Punjab}

Pettigrew describes Jat Sikh politics as factional and conflict ridden. ${ }^{18}$ Her work would suggest that the factionalism and corruption that mar the exercise of government in contemporary Punjab are, in fact, deeply rooted in Punjabi and Jat Sikh culture. Overall, her point is that Punjabi politics is neither class, caste/kinship, nor even genuinely party based, and is instead founded on vertical coalitions of individuals united in their quest for power and by shared enmities structured around a loose kinship core. Pettigrew and Izmirlan ${ }^{19}$ but also Hamza Alavi in the context of Muslim-dominated western Punjab ${ }^{20}$ — claim that political alliances cannot be caste-based because enmities tend to split extended lineages (biraderis) into at least two. This means that the Jat caste as a whole, but also individual Jat subcastes, are always split into at least two factions and they rarely create a joint political front. These authors all argue that conflicts over women, wealth, and land (zan, zar, zamin), but also political power, tend to obliterate the unity of extended lineages and even the unity of sibling sets as brothers frequently become embroiled in bitter disputes over succession. Pettigrew and Izmirlan argue that in order to fight each other, brothers or patrilateral cousins frequently align themselves with the enemies of their enemies. Moreover, dependents who rely on the Jats for their livelihoods-labourers and members of artisan and menial castes-feel compelled to take sides with their patrons, meaning that factional conflict also eliminates the possibility of their creating a joint political front on the basis of their subordinate, landless status. As a result, factions, unlike modern political parties, represent neither a shared ideology, nor specific class or caste interests, and their main 'function' is to help members gain power at the expense of rivals or at least to protect them against rivals.

${ }^{18} \mathrm{~J}$. Pettigrew, Robber Noblemen. A Study of the Political System of the Sikh Jats, Routledge \& Kegan Paul, London and Boston, 1975 .

${ }^{19}$ Ibid. H. Izmirlan, The Politics of Passion, South Asia Books, Columbia, 1979.

${ }^{20}$ H. Alavi, 'Kinship in West Punjab Villages'. Contributions to Indian Sociology, vol. 6, no. 1,1972 , pp. 1-27. 
In their work, Firth ${ }^{21}$ and Pocock ${ }^{22}$ separately argue that factions are impermanent and relative to specific circumstances, but Pettigrew argues that faction membership in Punjab remains surprisingly unchanging over relatively long periods of time and that what sustains it is the continuity of conflict. She further argues that the factional organization of Punjabi society has deep historical roots. Because Punjab lay on the main invasion route into India from the north, Sikhs had to organize into armed factions for protection and never felt a sense of ownership over the government that happened to rule over them. This was magnified by a long-held belief that to be a Sikh was to fight against authoritarian rulers and oppression. ${ }^{23}$ Factions, she claims, have 'been the only permanent form of organization that has persisted through the frequent collapses of central rule,24 and they have militated against the establishment of 'unitary rule' up until the second half of the twentieth century. ${ }^{25}$ Factions, and their members, concentrated primarily on their own individual profit and gain at the expense of the larger societal whole.

This account is appealing and could be used to explain the highly partisan and 'spoils-of-power' approach to politics of the ruling Shiromani Akali Dal. However, Saberwal suggests that this explanation is a-temporal and does not consider how specific political regimes at the state or national level might exacerbate or attenuate 'Punjabi factiousness'. ${ }^{26}$ It also seems to understate the difference between the warring bands (misls) of the eighteenth and nineteenth centuries and the parties and unions of the late twentieth century.

In Pettigrew's account, ideological commitments are irrelevant to how Jat Sikhs engage with politics. What matters to them are their personal enmities and their desire for power. Therefore political parties are merely vehicles through which they can obtain power

${ }^{21}$ R. W. Firth, 'Factions in Indian and Overseas Indian Societies'. British Journal of Sociology, vol. 8, no. 4, 1957, pp. 291-295.

${ }^{22}$ D. F. Pocock, 'Inclusion and Exclusion: A Process in the Caste System of Gujerat'. Southwestern Journal of Anthropology, vol. 13, 1957, pp. 19-31.

${ }^{23}$ Pettigrew, Robber Noblemen. See also H. Singh, The Heritage of the Sikhs, Manohar, Delhi, 1994.

${ }^{24}$ Pettigrew, Robber Noblemen, p. 26.

${ }^{25}$ Ibid. The term 'unitary rule' used by Pettigrew appears to be referring to state sovereignty.

${ }^{26}$ S. Saberwal, 'Robber Noblemen: A Study of the Political System of the Sikh Jats'. The Journal of Asian Studies, vol. 38, no. 2, February 1979, pp. 403-405. He suggests that during the period to which Pettigrew's study refers, factiousness might have been exacerbated by Nehru's determination to suppress the Akali Dal. 
and these are as a result largely interchangeable. However, the history of Indian Punjab since partition has, in fact, been marked by strong partisan and ideological commitments, especially among certain segments of the Sikh population who have supported the Akali Dal. ${ }^{27}$ Many Sikhs, particularly since the Congress-led attack on the Golden Temple complex in Amritsar, are deeply opposed to the Congress Party and would never vote for it: they do not see political parties as interchangeable.

The Akali Dal owes its birth to an early twentieth-century movement that sought to regain control over Sikh religious institutions and strip them of non-Sikh religious practices. The Shiromani Akali Dal was founded in December 1920 and soon began to focus on protecting the interests of the minority Sikh community. Pritam Singh argues that while other Indian regional parties had their ideological roots in the Congress Party, the Akali Dal is distinctive among regional parties in that it 'evolved out of the logic of Sikh history'. ${ }^{28}$ Moreover, ever since partition, when it started to work towards the creation of a Punjabi-speaking state, it has been in conflict with the Congress Party. Under Nehru's leadership the latter opposed this demand because it feared that it might give rise to the escalation of communal strife in a sensitive border area. It viewed the demand for a linguistic state as a disguised Sikh, and therefore communal, issue. And indeed, some Sikh leaders did see the furtherance of the Punjabi language as a Sikh issue. ${ }^{29}$ However, following Nehru's death, the Congress Party eventually gave in and a Punjabi-speaking state with a Sikh majority population emerged in 1966. This paved the way for the Akali Dal to obtain power in $1967 \cdot{ }^{30}$ However, the Congress Party subsequently engineered defections within Akali ranks and eventually brought down the government. The Akalis regained power in 1969, but the governor subsequently dissolved the state assembly in 1971 . Pritam Singh argues that this cycle of rising and deflating ambitions led the Akali Dal to demand greater autonomy for states inside India's federal structure.

\footnotetext{
${ }^{27}$ And this is not to mention the various leftist movements that once thrived in Punjab. See, for example, G. Singh, Communism in Punjab, South Asia Books, Delhi, 1994 .

${ }^{28}$ P. Singh, 'Class, Nation and Religion: Changing Nature of Akali Dal Politics in Punjab, India'. Commonwealth \& Comparative Politics, vol. 52, no. 1, 2014 , p. 68.

${ }^{29}$ A. S. Sarhadi, Punjabi Suba: The Story of the Struggle, APH Publishing, Delhi, 1970.

${ }^{30}$ The 1971 Census showed that Sikhs constituted 60.22 per cent of Punjab's population.
} 
Arguably the events that most strongly cemented the AkaliCongress opposition were the storming of the Golden Temple complex in 1984 by the Indian Army, Indira Gandhi's subsequent murder at the hands of her Sikh bodyguards, and the communal riots in which thousands of Sikhs were murdered in retribution for Indira Gandhi's death. During my fieldwork a number of Jat Sikhs told me that they would never vote for the Congress Party because it was responsible for the desecration of the Golden Temple and for the death of thousands of innocent Sikhs. Reflecting this mistrust, the Akali Dal has made alliances with a number of different political forces but never with the Congress Party. Post-1984, the SAD has consistently aligned itself with the Bharatiya Janata Party (BJP), thereby at least partially allaying fears that it was anti-Hindu and acquiring the support of a national-level political party.

Following the brutal repression and collapse of the Khalistan movement, the Akali Dal began to move away from identity politics, to focus its agenda on development, and to expand its base beyond its traditional land-owning constituency. Izmirlan reports that in the $1960 s$ most Dalits felt that the Akali Dal tended to exclude them and favour farmers. ${ }^{31}$ This is less true today as, over time, the SAD has sought to undermine Dalit support for the Congress Party by reaching out to them through a variety social welfare programmes, including the Atta Daal scheme, which entitles poor families to 400 free units of electricity, the Shagun scheme for poor brides from all communities, and the payment of old age pensions worth between Rs $25^{\circ}$ and 400 a month. Additionally, Akali politicians throughout Punjab have been disbursing grants for SCis to build gurdwaras, cremation grounds, and also to improve roads and drains in their neighbourhoods. However, as I have argued elsewhere, ${ }^{32}$ the Akali Dal has nevertheless often tended to support its wealthy Jat party workers at the SC's expense. And, finally, the SAD has likewise reached out to rich Hindu merchants by giving them important posts in local and provincial government.

By expanding its support base through both programmatic and clientelistic methods, the SAD has sought to secure a position as the state's dominant party. During his rallies, Deputy Chief Minister Sukhbir Badal made his ambitions clear by frequently claiming that

\footnotetext{
${ }^{31}$ Izmirlan, Politics of Passion. Thus many Dalits told me that the party that had most benefited them over the years was the Congress Party, and point to schemes like the Indira Awas Yojna.

${ }^{32}$ Martin, 'Rural Elites'.
} 
his party would rule Punjab for 25 years (raj karenge-pachi sal). To undermine the Congress Party and thereby achieve dominance, his party has not only used the enticements listed above, but also threats and violence. This, I argue, is what lies behind contemporary factional conflict in rural areas, not an inherent Jat Sikh factiousness.

\section{Responsive government}

On the ground, the most striking features of the current Akali government are not its policies and welfare schemes, but rather its omnipresence on the ground and its responsiveness to clientelistic requests. My informants frequently joked about how in the past politicians would present themselves at their supporters' weddings, funerals, and Akhand Paths, ${ }^{33}$ but that nowadays senior Akali politicians even turned up in people's homes to celebrate chicks hatching from eggs. And, indeed, in the constituency that I studied, both the elected leader-Gurjant Singh ${ }^{34}$ —and his younger brother were often on the road, visiting their constituents and attending events in people's homes. Perhaps even more importantly, Gurjant Singh spent his days helping supporters to obtain state services-doing what he and other politicians called social work, or seva in Punjabi and Hindi. Moreover, Gurjant Singh had an army of party workers who, as brokers, transmitted ordinary people's requests to him and who mobilized people for SAD political rallies and for elections. The Akali Dal, party workers boasted, was a hands-on party whose members braved the heat and the dust in order to help ordinary men and women in their daily struggles.

Given the dense thicket of red tape that surrounds Indian bureaucracy, ${ }^{35}$ politicians often dedicate at least some of their time to helping constituents obtain services that the state should, in theory, provide without their intervention. Much of the literature-some of which has been referred to above-focuses on how brokers help or impede people's access to state resources, but little appears to have

\footnotetext{
${ }^{33}$ An Akhand Path is the recitation of the Sikh Holy scriptures in a single reading, lasting more than 48 hours. These readings are done in honour of particular occasions and food is served to guests in attendance.

${ }^{34}$ Throughout the text I have used pseudonyms to protect the identity of my informants.

${ }^{35}$ See A. Gupta, Red Tape: Bureaucracy, Structural Violence, and Poverty in India. Duke University Press, Durham, 2012.
} 
been written on how members of provincial and national assemblies help citizens and/or brokers through their 'constituency work'. Bussel is one of the few who does: based on survey work she reports that citizens frequently bypass brokers to directly obtain the intervention of senior politicians. ${ }^{36}$ Broadly, her argument is that senior politicians often intervene on behalf of their constituents on a non-partisan basis. In this way they build their own personal network of supporters independently of political party structures.

One of the sources of the Akali Dal's electoral successes and popularity is the way in which its senior politicians have made extensive use of their influence to help people tear through bureaucratic red tape. Bureaucrats have to comply with politicians' requests because, as $Z_{\text {wart }}{ }^{37}$ and $\mathrm{Wade}^{38}$ have clearly shown, politicians can determine their future postings and promotion chances. I was unable to determine the precise extent to which politicians help constituents on a non-partisan basis, but, based on my visits to the local MLA (Member of the Legislative Assembly, state level), what was most immediately apparent was how much they help both ordinary citizens and their allied elected village council leaders (sarpanches) and brokers on a partisan basis.

Berenschot argues that citizens judge 'politicians and providers on the basis of their proven capacity to provide services to them, not on the basis of their capacity to provide efficient universal access to these services'. ${ }^{39}$ Gurjant Singh clearly falls into this category and was widely perceived as an effective politician. The fact that he was rich and close to the chief minister furthered bolstered his credibility as an effective politician. He has family ties and significant business interests in both Punjab and North America. Many of my informants made the exaggerated claim that he was so rich that he had been able to spend Rs 15 billion on his electoral campaign in 2012. Many

${ }^{36} \mathrm{~J}$. Bussel, 'Clients or Constituents? Distribution Between the Votes in India'. Draft prepared for presentation at the Berkeley Comparative Politics Colloquium, 2 April 2015, http://cpd.berkeley.edu/wp-content/uploads/2015/02/ Bussell-Clients-or-Constituents-Berkeley-Brokering-Votes-Conference-1.pdf, [accessed 5 March 2018].

${ }^{37}$ F. Zwart, The Bureaucratic Merry-go-round, Amsterdam University Press, Amsterdam, 1994 .

${ }^{38}$ R. Wade, 'The System of Administrative and Political Corruption: Canal Irrigation in South India'. The Journal of Development Studies, vol. 18, no. 2, 1982, pp. 287-328. See also R. Wade, 'The Market for Public Office: Why the Indian State is not Better at Development'. World Development, vol. 13, no. 4, 1985, pp. 467-497.

${ }^{39}$ Berenschot, 'Everyday Mediation', p. 892. 
were awestruck by the palatial grandeur of his four-storey home, with its underground parking that housed a fleet of Mercedes cars and SUVs. Perhaps more significantly for his reputation as a powerful man was his close friendship with the Punjab chief minister, a man whose allegedly huge (undeclared) personal fortune was popularly believed to equal that of the billionaire Mukesh Ambani of Mumbai. It was widely believed that the only politicians with any real power were the ones with close ties to the chief minister, who wielded his authority over the party and the state's civil administration with an iron fist.

Gurjant's wealth and contacts helped inspire confidence in his power to get things done, but his indefatigable work on behalf of loyal brokers and the constituents they represented, showed that he was ready to use his power on behalf of the people. He woke up at six o'clock to start making phone calls and then held his daily public session between eight in the morning until noon, during which his constituents flocked to him for favours. Later, throughout the afternoon, he was at the disposal of party workers who bombarded him with phone calls. Moreover, he appeared both omnipresent and omniscient: omnipresent because he attended a significant number of his constituent's weddings and funerals, but also as a result of the numerous pictures of him that adorned the roadsides as well as the reception rooms of his many party workers, and omniscient because his network of supporters, party workers, and even (allegedly) plain-clothes police officers kept him informed about people's problems as well as their loyalties, especially those party workers.

Party workers came from all walks of life, but the most prominent among them tended to be influential village-level leaders who were either village sarpanches or opposition faction leaders when the sarpanch belonged to the Congress Party. In theory, elected village councils (Panchayats) are meant to operate independently of party allegiances. The rationale for this is that allowing political parties to operate at Panchayat level is likely to undermine decentralized government as political parties rather than villagers might end up influencing, or even directly deciding on, the allocation of development projects and government schemes. However, Panchayat elections in Punjab have been, according to some of my informants, politicized along party lines since Beant Singh's Congress government, starting in 1992. In practice, this means that sarpanches need to clearly signal their political affiliation if they want to obtain government resources and favours. It therefore also means that unaffiliated 'fixers' cannot emerge, and that it is mainly through party-affiliated brokers or party workers that 
ordinary citizens gain access to the state. Thus, under the present Akali government, Congress sarpanches could not expect to access government resources and during the block samiti and Panchayat elections of 2013 some of them shifted their allegiance to the SAD. To ensure their loyalty, Gurjant Singh frequently asked these newcomers to vow their allegiance in a gurdwara. Party workers were also expected to demonstrate their loyalty by sporting the dark blue Akali turban, and also by gathering people and organizing rallies during elections. Many party workers told me that they had to use their own funds to do so. All of these practices served as ways to demonstrate support for the Akali Dal and, simultaneously, as ways of renouncing any allegiance to opposition parties.

In order to further ensure the sincerity of these displays, Gurjant required his party workers to report on each other's loyalties. There appeared to be many who, in order to get closer to him, were ready to denounce other party workers for being insufficiently diligent or for secretly supporting the opposition Congress Party. During my stay, I heard of cases of party workers secretly using their mobile phones to film or record each other doing or saying things that could be construed as disloyal to Gurjant and the Akali Dal. Moreover, during the run-up to the 2014 national elections, I was repeatedly told that Gurjant used plain-clothes officers to spy and report on people's political loyalties, including those of Akali party workers. In one village, for example, an ex-sarpanch whom I tried to interview just before the elections became very nervous when I asked him which party he supported and then cut the interview short. He told me that he did not know who I was, and that there were plenty of people like me, including plain-clothes police officers, going around checking on people's political allegiances. The fact that I was visibly a foreigner made no difference because, he claimed, leaders like Gurjant Singh had plenty of relatives in countries like Canada and the USA who worked on his behalf.

Perhaps unsurprisingly then, Gurjant's seeming omnipresence, omniscience, and omnipotence led some people to attribute supernatural qualities characteristic of holy men to him. Both he and his faithful supporters told a story about how a fortune teller had long ago predicted that he would one day become either a saint (sant) or a politician (neta). One of his more devoted Sikh followers even appeared to honour him over the first and tenth Gurus by hanging a large portrait of him above smaller ones of them.

Constituents and party workers crowded into his extravagant home to attend the daily 'court' sessions over which he presided-indeed, 
very much like a deity-with the power to miraculously resolve seemingly intractable problems with a single phone call. Flanked by two personal assistants and several heavily armed policemen, he placed calls to land record officers, the police, electricity board officers, and government doctors. Through his interventions people accessed everything from pensions, housing plots, and jobs to wheelchairs; among other things, school fees were waived and police investigations were influenced to favour supporters.

To the extent that this sort of political 'social work' helped speed up government functions that ordinary brokers were unable to tackle, Gurjant Singh's efforts were undeniably helpful. The problem was that he, and his party as a whole, seemed to intervene and to dispense the bulk of government services to his loyal party workers, which gave rise to widespread accusations of corruption.

Balwant Singh, for example, was one of Gurjant Singh's oldest and most loyal party workers. He had been sarpanch for eight consecutive five-year terms - 40 years in total — and had consistently succeeded in getting the majority of people in his village to vote for the Akali Dal. But his activities had also extended far beyond his own village, and he had actively campaigned for the party throughout the constituency. Gurjant first rewarded him by providing Balwant's son 'Sonny' with a job in one of his companies, and then eventually by making Sonny one of his two personal assistants. Along with Sonny's position, came immediate and preferential access to Gurjant Singh, which allowed his family to obtain a variety of material rewards. Gurjant had, for example, given Balwant and his brothers' families explicit permission to steal electricity to run their air conditioners during the summer, and therefore avoid electricity bills that could reach up to Rs 10,000 a month.

But Balwant obtained other far more substantial benefits. It was, for example, widely known that thanks to his political contacts he was able to broker police protection for the Sainsi community in his village, who constituted roughly a third of the village population, and who smuggled and sold illegal poppy husk (a popular opiate in Punjab). When the police planned a raid, friendly officers warned him with a phone call, and he in turn warned the Sainsis and allowed them to hide their merchandise in his farmhouse until the raid was over. It was widely accepted that it was because of this that Balwant had consistently secured the Sainsi vote for almost half a century. What was less clear was how he made money out of this, and whether he personally traded poppy husk. Many Jats in his village claimed that he 
did. He was also widely known to have used his political contacts to capture a valuable commercial property in the Tehsil headquarters to run a fertilizer and a commission agent business.

This was not an isolated case. In many of the villages that I visited people complained that Akali sarpanches and other party workers had free reign to loot the state and that they distributed government resources in a highly partisan manner. For example, in most villages I visited village common lands were being cultivated by Akali sarpanches and their allies. I have argued elsewhere that SCs rarely obtain their share of village common lands ${ }^{40}$ - a third of which is reserved for them by law-because upper caste Jats have illegally captured much of this land and do not even pay the usual nominal fee of Rs 8,ooo per year to cultivate it. ${ }^{41}$ Here I wish to briefly emphasize the fact that under the Akali government it was not just Jats who tended to control village common lands, but more specifically Jats who were closely affiliated with the ruling party. I was told, for example, that Balwant controlled most of the village common land in his village. In other villages, I heard accusations that Akali sarpanches had distributed village common lands almost exclusively among their allies. Congress Party supporters in Tullewal village, for example, told me about how the Akalis had distributed land among themselves by simply not advertising the date of the mandatory open auction at which farmers are meant to place bids for particular plots of land. The auction was held in the Akali sarpanch's house with only his allies present because no one else knew about the event. In Tullewal, as in Khanpur village, I was also told that village leaders had not even paid the rent due to the Panchayat for the tenancy of village common land. Gurjant Singh did not cause these things to happen, but he allowed them to happen by failing to get his administration to rectify the situation. However, when Congress supporters were the ones guilty of encroaching on government land, he intervened to get the administration to apply the law. In the past few years, government policy has been to clear village common land of encroachers in order to boost both village and state revenues. When this policy was carried out in Tullewal, for example, only known Congress Party supporters were evicted from their village common land farms.

\footnotetext{
${ }^{40}$ Martin, 'Rural Elites'.

${ }^{41}$ This fee was far below current market rates for irrigated agricultural land which had reached the unprecedented level of around Rs 40,ooo per acre.
} 
I also found evidence of partisan distribution of government resources such as NREGA work, ${ }^{42}$ pensions, subsidized pulses and wheat, and village infrastructure projects. All of this led to widespread accusations not only by Congress Party opponents, but also by ordinary Akali supporters who saw how party workers with close ties to Gurjant Singh got rich by appropriating resources that they should have had a share in.

\section{Congress opponents}

At first sight, there appears to be a contradiction between the partisan distribution of benefits and patronage, and the SAD's aim to extend its support base. Surely if it wanted to extend its support base, it would try to distribute benefits as widely as possible as failure to do so inevitably gives rise to accusations of partisanship and corruption? I suggest that although the SAD was extending its patronage more broadly than ever, one of the reasons for its partisanship regarding distribution of benefits was its deep rivalry with the Congress Party. Even in rural areas where the Shiromani Akali Dal had the support of well over half of the population, there were plenty of local politicians who, for one reason or another, were loyal to the Congress Party. Often, these were people with close ties to senior Congress leaders who did not join the SAD out of loyalty, despite attempts to bribe or coerce them into doing so. My observations indicate that the SAD saw no advantage in extending state largesse to loyal Congress supporters. In fact, they indicate that the SAD did everything to strengthen the positon of its own supporters at the expense of Congress Party workers. This, as I will illustrate, was one of the key factors behind the factional conflict that was pervasive throughout much of contemporary rural Punjab.

S. S. Gill has shown how the SAD weakened the Congress Party by getting influential workers from that Party to join its ranks during the block samiti elections of $2013 \cdot{ }^{43}$ It often did so by offering them party tickets and influential positions in government. At the village level, the SAD frequently approached influential Congress Party faction leaders with promises of future patronage and funds were they to join the

\footnotetext{
${ }^{42}$ The National Rural Employment Guarantee Act (NREGA) is a government scheme whereby all citizens are entitled to 100 days of paid manual work on government-sponsored micro-infrastructure schemes.

${ }^{43}$ S. S. Gill, 'Changing Economic Structure, Emergence of New Political Class and Elections in Punjab'. Unpublished article, 2014.
} 
SAD. Some leaders took the offer, others did not but gave the SAD only 'friendly opposition', and some actively resisted the SAD. A number of Congress Party leaders that I interviewed appeared to feel that opposing the SAD was either futile or dangerous. They thought it futile because it meant cutting oneself off from patronage and development funds, and they thought it dangerous because when bribes did not work Gurjant Singh-like the rest of the Akali leadership-frequently resorted to threats. The Congress ex-president of the municipal council in the Tehsil headquarters where I was based, was widely rumoured to be secretly collaborating with leading Akali politicians and to have done little effective campaigning for the Congress Party in the national elections of 2014. When I interviewed him he told me that the SAD threatened to close down his brick kilns on charges that he was illegally transporting bricks in trolleys pulled by tractors, even though SAD-supporting brick kiln owners who did the same faced no such legal problems. He nevertheless claimed that he remained loyal to the Congress Party, but other leaders from the Party disputed this claim, pointing out that he joined the SAD leaders for drinks in the evening on a daily basis. Others openly admitted to giving in to Akali pressures. Balbir Singh, a rich Jat Sikh landowner and long-standing Congress Party worker and sarpanch, told me that he had joined the SAD because if he did not he might lose his paddy threshing licence. And, finally, one SC Congress candidate for the position of block samiti member remained loyal to his party but barely campaigned for it in order not to antagonize the Akalis. A local Akali goonda-whom I call Gurbachan Singh-had told him that he and his friends would beat him up if ever he dared to actively campaign on behalf of the Congress Party.

Sukhvinder Singh and Lakhwinder Singh, two of the most influential Congress Party workers in the Tehsil where I carried out my research, were among those leaders who did not succumb to either bribes or threats, and who continued to actively support the Congress Party and resist the Akalis. They told me that Gurjant Singh had repeatedly attempted to lure them with promises of patronage, but that they had refused his offers. Both of them had been sarpanches in their home villages for several consecutive terms, and one of them had been the chairman of the local Market Committee and the other had once been block samiti chairman. Gurjant was interested in winning them over because they could potentially deliver important blocks of votes to the SAD, but they refused to join him because they both had close ties to the Congress Party-supporting Patiala royal family. 
Both of them continued to play an important role in the local Congress Party, but they paid a price for doing so. Those who, like them, did not bow down to the Akali Dal not only faced bureaucratic hurdles or were denied government patronage, but were also actively harassed, either with the help of the police or with the help of local goondas patronized by the SAD. Throughout my fieldwork I heard and read about stories of Congress Party workers being attacked by armed goondas and by the police, and about how many had been falsely implicated in drug trafficking, corruption, and even murder cases. Gill has reported on how the SAD dispensed gun licences to its supporters in order to fight Congress Party workers. ${ }^{44}$ Sukhvinder Singh told me that in the 2008 Panchayat elections, his son was assaulted by his SAD rivals while he was out supervising agricultural work in his fields.

Sukhvinder had traditionally controlled the Panchayat in the village of Mial Khurd and his Akali rivals—both there and in the neighbouring village of Mial Kalan-resented him for it. Since the SAD's rise to power, Gurbachan Singh-the goonda who was the son of his principal rival-had emerged as the leading gangster in Tehsil X. His job was to intimidate opponents, capture polling booths, and also (allegedly) provide the SAD with a cut from his drug-dealing activities. He was also apparently involved in what Pritam Singh calls a 'call girl racket' whereby he supplied wealthy businessmen and politicians with young college girls, in grabbing disputed urban properties, and in the gambling business. ${ }^{45}$ In exchange for his services to the party, Gurbachan was afforded police protection and had prospered. Lawyers at the Tehsil headquarters alleged that Gurjant Singh had ordered the police to let him operate freely; their evidence for this lay in the fact that, despite his blatant involvement in crime, the police had never charged him. Gurbachan was known to have threatened people at gunpoint, to have randomly beaten up people who dared to stare at him on the street, and was even rumoured to have killed a debtor and dumped him in an irrigation canal.

In 2008, when he had attacked Sukhvinder's son, the latter had come out of his house with a pump action shotgun and caused the assailants to flee by firing a couple of rounds into the air. However, Gurjant Singh had subsequently helped Gurbachan file an FIR for attempted murder against both Sukhvinder and his son, and both of

\footnotetext{
${ }^{44}$ Ibid.

${ }^{45}$ P. Singh, 'Punjab's Electoral Competition'. Economic and Political Weekly, vol. 42, no. 6,2007, p. 466 .
} 
them spent the weekend in jail before the courts reopened on Monday. Subsequently, during the 2013 elections, Gurbachan managed once again to place attempted murder charges against both Sukhvinder and Lakhvinder.

Gurbachan and his relatives captured the polling station in Mial Kalan and barred known Congress voters from entering its premises. When Sukhvinder and Lakhvinder heard about this, they and their followers made their way to the polling station and started chanting 'Death to the Shiromani Akali Dal (Shiromani Akali Dal Murdabad)'. A fight broke out and both parties started hurling bricks at each other, but Gurbachan's party had come prepared and was armed with Sikh ceremonial swords and metal rods, and was a larger group, and eventually the Congress supporters fled. Sukhvinder received blows to his head and ended up in hospital. Moreover, once again Gurbachan managed to get the police to place attempted murder charges against Sukhvinder and various supporters, including Lakhwinder. Five police officers were present throughout the whole episode, but they did nothing to prevent either the ballot stuffing or the fight.

In neighbouring Mial Khurd the Akalis used the police to rig the block samiti elections. Sukhvinder's faction was the stronger one there, so Gurbachan would have found it more difficult to capture the polling station. Instead, the Akalis got the police to capture the polling station and stuff the ballot boxes. The Congress Party insisted that it was winning by 300 votes and that the Akali candidate had probably obtained no more than 70 votes. The fact that only one out of the five elected Panchayat members was an Akali clearly gives credence to their claims because people do not vote for village committee members (panches) from one faction and for sarpanches from another. Ironically, this meant that although the Akalis had obtained a sarpanch, they were unable to run the Panchayat because they lacked the necessary majority to pass resolutions.

Gurjant Singh subsequently tried to get Sukhvinder and the Congress panches to collaborate with the Akali sarpanch. However, Sukhvinder refused, saying that he did not care if the Panchayat was unable to do any work for the next five years because it lacked the quorum necessary to do so. His son, who claimed that the Akalis together with Gurbachan had ruined his life, was even more vengeful, saying that when the Congress Party returned to power he would destroy Gurbachan and his entire family. Although the rivalry between Sukhvinder's and Gurbachan's families was an old one, I would suggest that Akali interference on Gurbachan's behalf exacerbated it greatly. 
According to Sukhvinder, Gurbachan's father had started resenting him half a century earlier when he had successfully reclaimed and then cultivated what had seemed like sandy wasteland. His resentment increased further when Sukhvinder added political successes to his economic ones. However, had it not been for party political interference, their rivalry may not have escalated to the extent that it did. As another opposition Congress Party worker put it: 'High-ranking politicians don't resolve disputes; they aggravate them. If someone asks me to help resolve some dispute, I'll approach the opposing party and try to engineer a compromise (samjhota). An Akali party worker on the other hand will use his power to get the police to bring charges against the opposing party and, as a consequence, the parties will never speak to each other again.' The view that village-level factional conflict was due to the Akali Dal in particular, and political parties in general, was widespread. As a result, a number of sarpanches and panches claimed not to be aligned with any political party; they said their work was to deliver development (vikas) to their villages and not to become entangled in party-based rivalries. For example, one sarpanch told me that his work was to serve the people and that in order to be able to do such work, he aligned himself with whatever party was in power.

\section{Factionalism and village government}

Sukhvinder's village was one of many villages where factionalism, exacerbated by political meddling, meant that Panchayats could not operate effectively, if at all. In Sukhvinder's village the Panchayat lacked the quorum necessary to take decisions. In other villages Panchayats may have had the necessary majority, but resentful Congress Party opponents did everything in their power to undermine their initiatives. Sarpanches complained about how opponents found fault with everything they did and initiated complaints and placed RTI (right to information) requests in order to entangle them in corruption charges. They looked for the slightest pretext to entangle sarpanches in court cases.

The case of the World Bank water tanks clearly illustrates how politically fuelled factionalism, and not just 'leakages' through corruption, undermined village development schemes. Throughout Punjab, the World Bank has financed the construction of water tanks worth up to Rs 30 million. The condition for obtaining them was that the Panchayat rather than the state water department would take 
care of charging villagers for the electricity used to run the tanks. The policy was in line with the World Bank's push towards cutting government expenditure by devolving state functions to local bodies and its immediate aim appeared to be to cut the large losses being incurred by the water department.

I was told that water department losses were partly due to the fact that people felt entitled to free water and set up illegal connections to the water mains by either bribing water board officials or by having recourse to the political patronage of a party worker (usually the village sarpanch). Officials at the Punjab Water Board in Tehsil X told me that poor people were the ones most likely to set up illegal water connections and that in the process they often caused leaks in the supply system as a whole. Wealthier farmers were less likely to set up illegal connections (though sometimes they did too) because they had opted out of the public water provision system by setting up private water supplies with the aid of submersible motors. Significantly for the purpose of my current argument, senior politicians-and not just brokers-encouraged free riding by allowing supporters to get away with not paying for water.

Water Board officials complained that it was impossible for them to deal with water theft not only because of its scale (implying that it would be impossible for them to bring entire villages to account for stealing water) but also because of political interference. They complained that everyone in every village had, or at the very least boasted that they had, political connections of some sort. They claimed that the poor who stole water often relied on Jat sarpanches and brokers connected with senior politicians to help them evade punishment for water theft. Although they did not elaborate with examples, my informants hinted that politically connected people could get charges for water theft withdrawn. Perhaps more ominously for the officers with whom I spoke, people charged with water theft might complain about harassment by Water Board officials to the local MLA, who might then act to hamper their career advancement prospects or even get them transferred to undesirable locations. One officer claimed that political interference made it impossible for him to do his job properly. The officials' fear of politicians became even clearer when I asked them if the local MLA interfered much in their affairs. The most senior officer in the room became visibly nervous and said that they had merely been discussing generalities, adding that there was no political interference in his jurisdiction. In different departments other officers, including the tehsildar (the local revenue officer) and 
a senior Cooperative Bank manager, were similarly nervous about discussing their political masters. Those who did, and who provided details about political interference, asked me to keep what they had told me off the record.

While the World Bank's community-run water tanks may have helped alleviate the state's budget deficit by reducing the need for personnel to administer village water supplies, they appear to have been less successful in actually providing villagers with water. In most villages these water tanks were not operating, and in the villages where they were, it was because the local MLA had given their sarpanches permission to set up illegal electrical connections to run them. Because of factional rivalries between Jats contending for village leadership, the ruling Panchayats in all three villages had been unable to gather the money necessary to pay the electricity bill. In all of these villages the faction that did not control the Panchayat did everything in its power to sabotage its work, including not paying its share of the cost of electricity necessary to run the World Bank water tanks.

In Kotli village, for example, aggrieved Congress Party supporters not only prevented the Akali sarpanch from obtaining the quorum necessary to initiate development work, they also refused to pay their share of the electricity bill to run the water tank. Their leader, Davinder Singh, claimed that the Akalis had won the 2013 Panchayat elections fraudulently. He claimed to know that Gurjant Singh had threatened the presiding officer with demotion if he failed to deliver an Akali victory in the village. The final result was 311 votes for the Akalis and 310 votes for the Congress Party. Davinder claimed that the fraud had taken place at some stage during the counting process as he claimed to know that more than 310 people had voted for him. The fact that, as in Sukhvinder's village, the Akalis only had two Panchayat members (including the sarpanch) out of five and that they did not have the quorum necessary to pass resolutions also led Davinder to claim that there must have been some sort of fraud.

For the Akalis to obtain a majority in the Panchayat, Gurjant Singh's younger brother had assured the Akali leader in Kotli that he would get one of the SC panches to join his faction. He said that he would first ask him nicely, but that if this did not work he would threaten to beat him up or to place fake police charges against him. The Akalis demonstrated their resolve to do so when they roughed up one of the $\mathrm{SC}$ Congress supporters in the village. The SC in question was one of Davinder's loyal supporters, and while Davinder had been sarpanch he had rewarded her with the use of the large plot of land that surrounded 
the water tank. The woman grew vegetables on the land and used the tank to water them. When the Akalis came to power, they decided to evict her, claiming that she was using up all of the water. When she refused to budge, a group of young Akalis assaulted her. A Congress supporter used his mobile phone to film the event and showed me how the Akalis had pulled the woman's hair and torn her clothes off. The Congress-supporting SCs were indignant and vowed to block all Akali initiatives and never to give them the quorum they needed to run the Panchayat. Their first vengeful act was to refuse to pay their share of the bill to run the water tank. The Akalis nevertheless managed to collect Rs 70,ooo to keep the tank running, but everyone in the village had doubts about whether they would be able to continue to do this.

As a result of these conflicts, and the SAD's tendency to paralyse local government, many people were fed up not only with them, but also with the political status quo in the state. Political parties, they claimed, made everything rotten (kharab karte hain) and village life unbearable. My evidence seems to suggest that it was principally in villages without loyal and/or influential local Congress Party leaders that people were able to extricate themselves from factional conflict. Balwant's principal opponent in his village was a staunch Congress supporter, but since he had no chance of ever winning an election at village level and did not do much to counter Balwant's influence, factional conflict never escalated. And in villages where rival factional leaders were both Akalis-unlike in those where they were split between Congress and the Akali Dal-people were more easily able to compromise. Thus I found out about two villages where rival Akali factions had simply agreed to take turns controlling the village Panchayat. The rival factions had agreed that one party would take control for five years and the other for the following five years. In both cases, this agreement was made solemnly in a gurdwara, in the presence of all key village notables. This arrangement did not ensure transparency in the distribution of government goods, and I heard some people grumble about how the Panchayat was principally working for its factional supporters. Nevertheless, almost everyone I spoke to in these two villages said that at least their villages were peaceful and some members of the opposition faction claimed that their Panchayats were doing good work for the entire village. The fact that it was in villages without loyal and/or influential local Congress Party leaders that people were able to escape factional conflict further corroborates my contention that factionalism is exacerbated by political party rivalry. 
Finally, I found out about one village where people eschewed factional conflict by rejecting both the Akali Dal and the Congress Party. After years of factional strife, the village elected a pious ex-Akali in his late sixties who had-in protest against Akali high-handedness and corruption-declared his support for the anti-corruption Aam Admi Party (AAP). In almost all of the villages I visited, people accused their sarpanches of corruption, but I heard no such accusations against him. He told me that if you knew the rules and procedures, you could get some things done without contacts and bribes. He did admit, though, this could take longer and that the Panchayat might not receive as many benefits as one affiliated with the ruling party. He had, for example, managed to obtain $45^{\circ}$ Adhar cards for villagers without paying the Rs 400 demanded by government officials to expedite the process, but the cards had been delivered after several months rather than after the 15 days that the process would have taken had he paid a bribe.

\section{Conclusions}

In his article on fixers, James Manor illustrates how brokers and fixers play a positive role in the delivery of state services when provincial governments act in an inclusive manner. Manor uses Digvijay Singh's government in Madhya Pradesh during the 1990s to illustrate the benefits of non-partisan governance. Digvijay Singh was willing to include members of the opposition BJP in the various committees that his government created for schools, watershed development, and forest management. Moreover, he devolved substantial powers and resources to Panchayats. The implications for fixers were twofold. On the one hand, the proliferation of government committees reduced the need for their services because villagers wanting a new school, a tubewell, and so on could directly approach the relevant committee. On the other hand, some fixers recognized that being elected to these bodies offered them opportunities to 'make creative use of their skills at representation and lobbying'. ${ }^{46}$ They could do so safe in the knowledge that their association with the current ruling party would not damage their careers by linking them to the sort of partisan and corrupt politics described in this article. While taking up government

\footnotetext{
${ }^{46}$ Manor, 'Small-Time Political Fixers'.
} 
positions meant that they became brokers rather than fixers-in Manor's sense of the term-they were able to use their skills to benefit people on a more universal and non-partisan basis.

On the other hand, Manor presents Andhra Pradesh under Chandrababu Naidu's Telugu Desam party in the late 1990s as an example of partisan government similar to that described here. Chandrababu Naidu successfully sought to maximize his personal dominance, staffed government institutions with loyalists, and denied substantial powers and resources to Panchayats because he could not prevent members of the opposition from being elected into them. As a result of partisan government, Manor argues, fixers hesitated to get involved with the Telugu Desam Party and only party loyalists were able to mediate between citizens and the state. Fixers were averse to being manipulated by politicians and feared that they might incur the wrath of the Congress Party and forfeit any influence under a future Congress government.

From these brief summaries, it becomes apparent that contemporary Punjab under the Akali Dal resembles Andhra Pradesh under the Telugu Desam Party far more than it does Madhya Pradesh under Digvijay Singh. In fact, my account suggests that the SAD has taken partisan government a step further by arming and protecting both local criminals and party loyalists, and by centralizing control over Panchayats-like Chandrababu Naidu — as well as by rigging elections against opposition candidates. Some local leaders/brokers are clearly uncomfortable with this situation and want to distance themselves from party politics, much like Manor's Andhra Pradesh fixers. They attribute endemic factionalism to the Akali Dal's partisan meddling. When they nevertheless decide to become active in Panchayat politics and are then elected into office, they often claim not to be working for any political party but rather for their village as a whole. However, the politicization of Panchayats makes it difficult for non-aligned sarpanches - such as the AAP sarpanch briefly alluded to above- to obtain substantial benefits, and sarpanches often find themselves approaching Akali politicians in order to do so.

However, while some local leaders/brokers were uncomfortable with the Akali Dal's partisan form of government, there were also plenty of people who were willing to use their brokering skills within the framework of the Akali regime. Unlike the Andhra fixers who avoided getting involved because they worried about their reputations and feared retribution when the opposition came back to power, people like Gurbachan-and others described here-did not seem 
bothered either about their reputations or about the prospect of future retribution at the hands of Congress rivals. In many cases sarpanches appeared willing to at least partially sacrifice their reputations for the shorter term, but potentially substantial, benefits of association with the SAD government. Links with senior SAD politicians allowed sarpanches not only to capture village common lands for themselves and their allies, but also to siphon money out of government development schemes and even to get free electricity to run their air conditioners. Balwant, one of the sarpanches referred to, did not need to worry about his reputation because he had a virtually captive vote bank by virtue of the fact that he provided them with cover for their poppy-husk smuggling activities. So long as he provided them with protection, he was largely free to operate with impunity.

Other sarpanches may not have had the benefit of captive vote banks, but politically fuelled village-level factionalism ensured that they cared only for their reputations among supporters of the SAD since they did not expect to get any votes from confirmed Congress Party supporters. Moreover, they seemed to regard future retribution as a regrettable, but entirely natural, course of events. Thus, they not only distributed government programmes, development schemes, and village common lands among their allies, but also actively used their links to politicians like Gurjant Singh to harm their Congress rival's interests-for example, by evicting them from village common lands or implicating them in fake police cases. Congress Party members like Sukhvinder and his son, who were particularly badly treated by the Akali Dal, vowed revenge when the Congress Party returned to power. One of the key arguments in this article is that factionalism was itself exacerbated, or even produced, by partisan government. Had it not been for the fact that a partisan police force looked the other way when Gurbachan and his clan rigged local government elections and that it had, on several occasions, helped them place fake charges against Sukhvinder and his allies, then perhaps Sukhvinder and his son might have been less keen on taking revenge and less averse towards cooperating in the management of village affairs.

So, to return to my initial question: why did a government whose leaders were ostensibly committed to more inclusive, responsive, and even efficient government, free from the taint of corruption, govern in a partisan manner that ended up exacerbating both corruption and local conflicts? The answer, I suggest, lies less in the inherent factionalism of the Jat social order-as argued by Pettigrew-than in the animosities that fuel political competition between the Congress 
Party and the Shiromani Akali Dal. It is important to remember the history of conflict between the two political parties and to consider the fact that the Congress Party has historically used its own might to undermine the Akali Dal wherever possible. It is this rivalry that generates politically biased government and that prevents fixers and brokers from playing a more constructive and impartial role. Fed up with the antagonistic and partisan politics of the main parties in the state, in 2014 many people were placing their hopes on the Aam Admi Party, with its promise of clean and impartial government. 